\title{
Quality and antioxidant characteristics of 'Yakju' prepared with pigmented rice flour 'Nuruk'
}

\author{
Hong-Bi Han ${ }^{1}$, Hee-Won Lee ${ }^{1}$, Bok-Seon Kim ${ }^{1}$, Cheol-Min Kim ${ }^{1}$, Hyo-Gyeong Woo ${ }^{1}$, \\ Jae-Hee Jeong ${ }^{1}$, So-Mang Kim ${ }^{1,2}$, Chang-Ki Huh ${ }^{1,2 *}$ \\ ${ }^{1}$ Department of Food Science and Technology, Sunchon National University, Suncheon 57922, Korea \\ ${ }^{2}$ Research Institute of Food Industry, Sunchon National University, Suncheon 57922, Korea
}

\section{유색미(다향흑미) 쌀가루 개량 누룩제조와 이를 이용한 유색미 약주의 품질과 항산화 특성}

\author{
한홍비 $^{1} \cdot$ 이희원 ${ }^{1} \cdot$ 김복선 $^{1} \cdot$ 김철민 $^{1} \cdot$ 우효경 $^{1} \cdot$ 정재희 $^{1} \cdot$ 김소망 $^{1,2} \cdot$ 허창기 $^{1,2 *}$ \\ ${ }^{1}$ 순천대학교 식품공학과, ${ }^{2}$ 순천대학교 식품산업연구소
}

\begin{abstract}
A simple technology to manufacture 'Nuruk' with pigmented rice and 'Yakju' with improved quality and functionality was developed. Yakju (designated WY and PY, respectively) was prepared with white rice flour Nuruk (WN) and pigmented rice flour Nuruk (PN), and their qualities were compared. The enzyme activities of Nuruk revealed that PN had higher $\beta$-amylase activity (1,186.67 Saccharogenic acitivty, SP/g) and higher protease activity (378.90 tyrosine $\mathrm{mg} / \mathrm{min}$ ) than WN. During 11 days of fermentation, the $\mathrm{pH}$ of PY was steady in the range of 4.77-4.58, whereas the $\mathrm{pH}$ (4.82) of $\mathrm{WY}$ decreased to 3.90 on day 3 of fermentation and then increased to similar $\mathrm{pH}$ of $\mathrm{PY}$ until the fermentation was completed. The titratable acidities of PY and WY increased to $0.40-0.48 \%$. The ethanol content of PY and WY increased to $13.43 \%$ ad $13.23 \%$, respectively, on day 5 , after then PY showed higher ethanol content than WY until day 11 of fermentation. The organic acid content of PY $(1,225.87 \mathrm{mg} \%)$ was higher than that of WY $(1,021.69 \mathrm{mg} \%)$. The antioxidant activities of PY were twice as high as those of WY, and the total polyphenolics and total flavonoid contents of PY were also higher $(35.96 \mathrm{mg} \%$ and $19.01 \mathrm{mg} \%$, respectively) than those of WY $(16.29 \mathrm{mg} \%$ and $6.36 \mathrm{mg} \%$, respectively). Sensory scores on color, flavor and taste, and overall preference were higher in PY than in WY.
\end{abstract}

Key words : Nuruk, Yakju, quality characteristics, antioxidant characteristics

서 론

쌀은 동양인의 가장 중요한 식량자원으로 생체 에너지의 대부분을 차지하고 있으며, 우리나라에서 오랜 기간 주식으로 이용되어 왔다. 최근 현대인들의 만성질환 및 성인병 등의 사 회적인 문제가 대두됨에 따라 건강한 삶을 위해 기능성을 가
진 소재로서 유색미에 대한 관심이 높아지고 있으며, 주식으 로 기존의 백미에서 유색미로 대체하여 섭취하는 경향이 증 가하고 있다(Choi, 2018; Kwak, 1999b). 1990년에 중국에서 처음으로 유입되어 전남지방을 중심으로 재배되어 온 유색미 는 적갈색부터 흑자색에 이르는 천연색소인 안토시아닌계 색 소를 함유하여 항산화 기능성이 높고 식이섬유가 풍부하며

*Corresponding author. E-mail : hck1008@sunchon.ac.kr, Phone : +82-61-750-3251, Fax : +82-61-750-3250

Received Received 10 June 2020; Revised 13 November 2020; Accepted 30 December 2020.

Copyright (c) The Korean Society of Food Preservation.

This is an Open Access article distributed under the terms of the Creative Commons Attribution Non-Commercial License (http://creativecommons.org/licenses/by-nc/4.0) which permits unrestricted non-commercial use, distribution, and reproduction in any medium, provided the original work is properly cited. 
미네랄, 단백질 함량이 높고 차진 맛과 독특한 향미를 지녀 식품학적으로 이용가치가 높다. 유색미는 안토시아닌계 색소 를 함유하고 있으며, 미강층에는 cyanidine 3-O- $\beta$ - $D$-glucoiside 및 peonidine 3-O- $\beta-D$-glucoiside 등을 함유하여 항산화 기능 성이 높은 것으로 보고되어 있다(Sin, 2019). 하지만 이와 같 은 기능성을 함유하고 있는 유색미의 생산량은 전체 쌀 생산 량의 약 $5 \%$ 에 불과하며, 유색미를 활용한 가공식품 역시 많 지 않아 그 소비량은 점차 줄어들고 있는 실정이다 $(\mathrm{Sin}$, 2019). 최근 유색미를 이용한 선행연구에서는 식혜, 껌, 간장, 우동 등의 가공품에 대한 연구는 보고된 바 있으나, 주류에 유색미를 활용한 사례는 거의 없다(Kim 등, 1999a).

다향흑미 유색미 품종은 전남농업기술원 식량작물연구소 에서 육성하여 품종 등록한 유색미 품종으로, 품종보호 출원 제2017-118호로 2017년 2월 27일자에 출원되어 2018년 6월 25일자로 품종보호권 등록번호 제7257호로 등록된 품종이다 (Huh 등, 2019). 다향흑미는 다른 유색미에 비해 흑색 정도가 양호하고, 메벼이며 향이 매우 뛰어나다. 또한 현미천립중이 $24.2 \mathrm{~g}$ 으로 다소 크고 중원형의 현미모양을 나타내고 있다. 기존의 유색미는 향이 부족한 면이 있지만 다향흑미는 향이 풍부하여 약주에 첨가하였을 때 좋을 것으로 판단되어 유색 미 품종으로 다향흑미를 선택하여 약주에 첨가하였으며, 다 양한 기능성을 함유한 유색미 약주를 개발하고자 하였다.

술은 탄수화물 등의 원료 성분이 젖산, 곰팡이 등의 미생 물 분해작용과 알코올 발효를 통해 당, 유기산 등의 여러 성 분이 함유된 발효음료로 인류 문화와 함께 자연 발생적으로 생성 음용되어 왔으며, 우리나라 전통주로는 약주, 탁주가 있 다(Shin 등, 2016b). 그 중 약주의 전통적인 양조법은 백미, 찹쌀 등의 원료와 코지, 효모를 물과 함께 투입하여 발효 중 3 번에 걸친 원료 투입으로 영양원의 생성과 자화의 평형을 맞춰 고농도의 알코올을 생산하는 병행복발효로 진행된다 (Seo와 Ryu, 2002). 최근에는 기능성 청주, 약주에 대한 소비 자 수요가 증가하며, 주류 업계에는 신제품 및 리뉴얼 제품 출 시로 시장 상황에 대응하고 있으며(Seo, 2002; Shin, 2016b), 젊은 층에 인기를 얻기 위해서는 누룩향이 강한 약주에서 향 이 가볍고 깔끔한 제품으로 변화되어야 한다.

재래 누룩은 누룩 중에 생육하는 여러 균주의 조성에 의해 양조되므로 지방에 따라 다양한 누룩이 있으며, 제조방법에 따라 여러 형태의 누룩이 된다. 개량 누룩은 술덧의 안전한 발효와 잡균 오염이 방지되어 품질이 균일한 술이 제조되는 장점이 있다. 누룩에 따라 효소활성, 알코올 발효력 등이 달 라지므로 약주의 풍미, 맛, 색상 등의 품질 및 기능성에 큰 영향을 미칠 것으로 판단된다(Woo 등, 2010).

현재 약주에 대한 선행 연구로는 전통 약주 중 재래식 형 태의 제조 기술 개발, 원료 및 술덧의 이화학적 성분 분석, 누룩 및 술덧 중의 미생물과 효소의 분포, 다양한 한약재를
첨가한 약주의 개발 등이 진행된 바 있는데(Lee 등, 2011), 대부분 발효 미생물에 대한 연구에 치우쳐 있으며, 개량누룩 에 대한 공정과 다양한 쌀가루를 이용한 주류개발에 관한 연 구는 아직 미진한 상황이다(Lee 등, 2019). 본 연구에서는 선 행연구로 진행한 누룩 제조를 현장에서 보다 쉽고 공정이 간 편한 제조 기술로 특허 등록한 무증자 쌀가루 개량누룩 제조 기술(Huh 등, 2018)을 유색미(다향흑미) 누룩 제조에 응용하 였고, 백미 쌀가루 개량누룩을 백미에 첨가한 일반 약주와 유 색미 쌀가루 개량누룩을 유색미에 첨가한 유색미 약주를 제 조하여 두 약주의 품질과 항산화 특성을 비교하였다.

\section{재료 및 방법}

\section{실험 재료}

본 실험에 사용한 누룩 및 약주 제조용 유색미인 다향흑미 (2018년산)는 전남농업기술원 식량작물연구소, 백미(2018년 산, 한아름쌀)는 (주)광양주조공사에서 확보하여 실온에서 보 관하면서 사용하였고, 누룩 제조용 종국은 시중에 판매 중인 백국(백국조제종국, Chungmoo Fermentation, Ulsan, Korea) 을 확보해 사용하였다.

\section{쌀가루 개량 누룩의 제조}

쌀가루는 백미. 유색미를 건식제분법으로 체(100목)가 장 치된 pin mill(5마력, 경창기계)에 투입하여 $(500 \mathrm{~g} / \mathrm{min})$ 분쇄 하여 제조하였다. 쌀가루 개량 누룩 제조는 백미, 유색미 쌀 가루에 $100^{\circ} \mathrm{C}$ 의 온수 $400 \mathrm{~mL}(40 \%)$ 를 가하여 뜨거운 상태에 서 반죽한 뒤, 반죽의 온도가 $30^{\circ} \mathrm{C}$ 에 도달했을 때 백국(백국 조제종국, Chungmoo Fermentation)을 각각 $0.3 \%$ 씩 첨가해 2차 반죽하였다. 반죽 후 누룩 제조 성형 틀에 넣고 성형해서 누룩 상자에 넣고 $30^{\circ} \mathrm{C}$, 습도 $85 \%$ 에서 48 시간 동안 1차 배양 하였다(DS-130S, Daewon, Bucheon, Korea). 2차 배양은 누 룩 상자의 뚜껑을 제거하고, $25^{\circ} \mathrm{C}$, 습도 $85 \%$ 에서 누룩을 상자 에 기대어 7 일간 배양한 다음 수분함량이 $10 \%$ 내외가 되게 건조시켜 백미, 유색미 쌀가루 개량 누룩을 제조하였으며, 제 조공정은 Fig. 1A, 사진은 Fig. 2A와 같다(Lee 등, 2019).

\section{쌀가루 개량누룩을 첨가한 약주 제조}

쌀가루 개량누룩 첨가 약주의 제조는 백미, 유색미를 각각 $2 \mathrm{~kg}$ 을 수세하여 5시간 물에 침지하고 2시간 물 빼기 후 1 시 간 동안 증자하고 $30^{\circ} \mathrm{C}$ 로 냉각하여 제조된 백미, 유색미 쌀가 루 개량 누룩을 각각 $200 \mathrm{~g}$ 과 탁주효모(Takju yeast, Bioland, Ansan, Korea) $6 \mathrm{~g}$ 및 양조용수 $3 \mathrm{~L}$ 를 첨가해 $23-25^{\circ} \mathrm{C}$ 에서 11 일간 발효시켰다. 발효 종류 후 위의 맑은 액을 Filter paper No.2(Advantec, Toyo Roshi Kaisha, Tokyo, Japan)로 
(A)

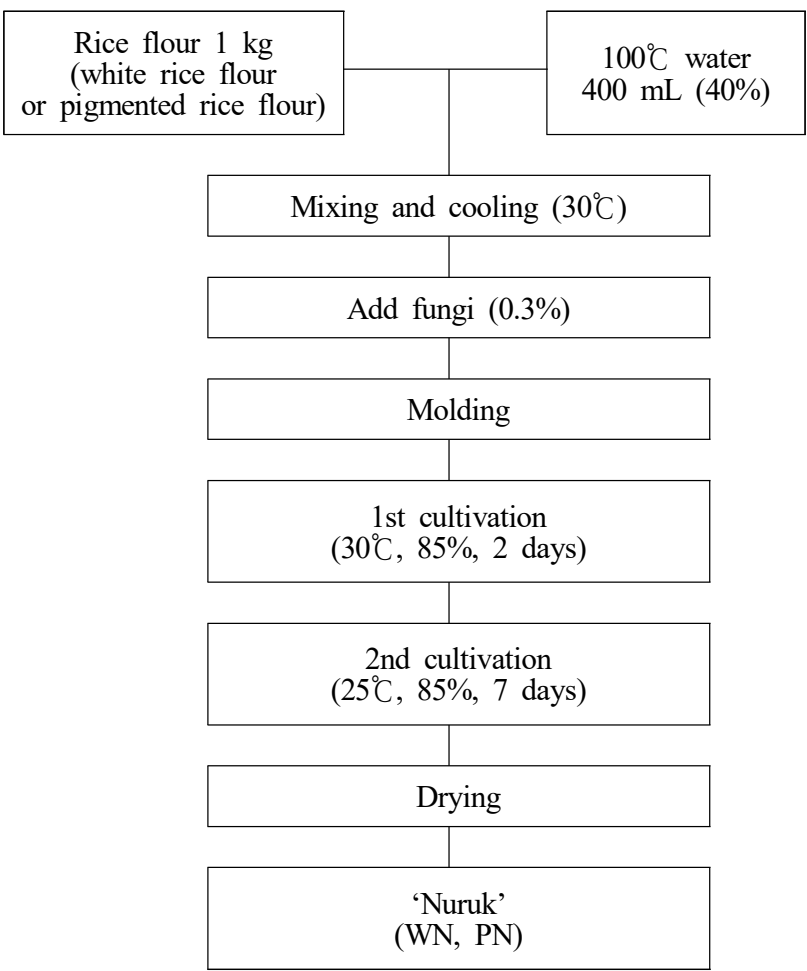

(B)

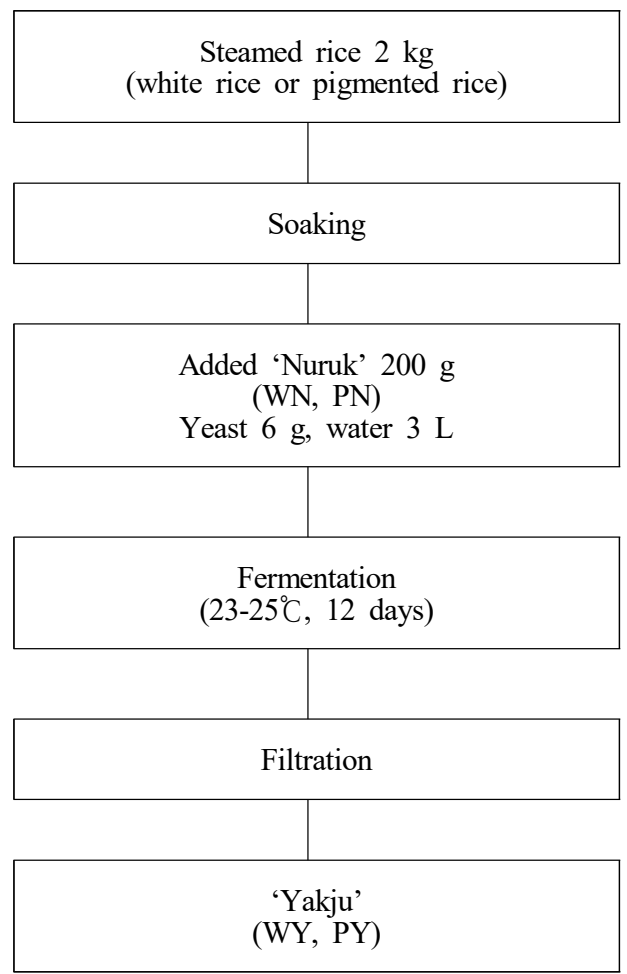

Fig. 1. (A) Process for the preparation of white rice flour 'Nuruk' and pigmented rice flour 'Nuruk'; (B) Process for the preparation of 'Yakju' made with white rice flour 'Nuruk' and 'Yakju' made with pigmented rice flour 'Nuruk'.

WN, white rice flour 'Nuruk'; PN, pigmented rice flour 'Nuruk'; WY, 'Yakju' made with white rice flour 'Nuruk'; PY, 'Yakju' made with pigmented rice flour 'Nuruk'.
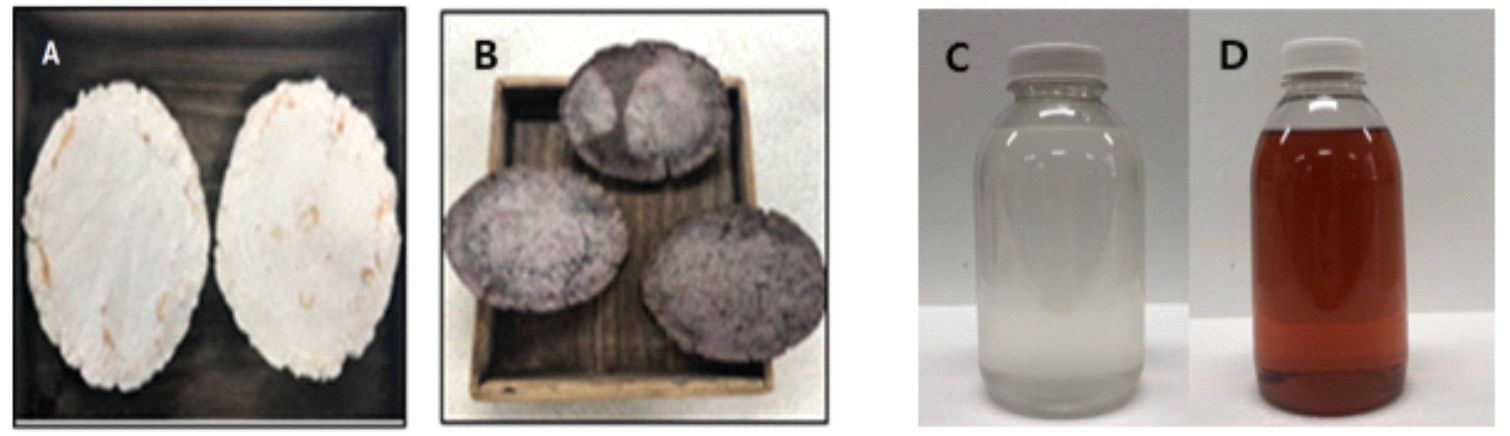

Fig. 2. Photographs of 'Nuruk' and 'Yakju'.

A, white rice flour 'Nuruk'; B, pigmented rice flour 'Nuruk'; C, 'Yakju' made with white rice flour 'Nuruk'; D, 'Yakju' made with pigmented rice flour 'Nuruk'.

1차 여과하고, 2차(MF-100, Hanil, Daejeon, Korea)로 원심 분리하여 약주를 제조하였으며, 제조공정은 Fig. $1 \mathrm{~B}$, 사진은 Fig. 2B와 같다.

\section{누룩의 효소활성 측정( $\beta$-amylase, $\alpha$-amylase, protease)}

당화력 측정( $\beta$-amylase 활성)은 국세청기술연구소 주류분석
규정(NTS Liquors Licence Aid Center, 2010a)에 따라 측정하 였다. 즉, $2 \%$ 전분용액 $50 \mathrm{~mL}$ 와 $\mathrm{pH} 5.0$ 의 초산염완충액 30 $\mathrm{mL}$ 를 취하여 $55^{\circ} \mathrm{C}$ 항온수조에서 10 분간 예열한 다음 효소용 액 $10 \mathrm{~mL}$ 를 가하여 60 분간 당화시킨 후 $0.5 \mathrm{~N} \mathrm{NaOH} 10 \mathrm{~mL}$ 를 가하고 냉각시켜 효소작용을 정지시켰다. 환원당 측정은 Fehling 용액 $10 \mathrm{~mL}$, 물 $40 \mathrm{~mL}$, 포도당 표준용액 $10 \mathrm{~mL}$ 를 
가해주고 끓여주면서 포도당표준용액으로 적정하였으며, 다음 식에 의해 계산하였다.

Saccharogenic power(SP) $=\frac{(\mathrm{B}-\mathrm{S}) \times 2}{\mathrm{~W} \times \mathrm{h}}$

2: Factor(20/10)로서 포도당표준용액 $(2 \mathrm{mg} / 1 \mathrm{~mL})$ 과 사 용된 표준용액 $10 \mathrm{~mL}$ 의 양에서 산출된 수치임

$\mathrm{W}$ : 시험용액 $10 \mathrm{~mL}$ 에 함유된 검체의 양 $(\mathrm{g})$

$\mathrm{h}$ : 반응시간(h)

$\mathrm{S}$ : 포도당 표준용액의 소비 $\mathrm{mL}$ 수

누룩의 액화력 측정 $(\alpha$-amylase 활성 $)$ 은 국세청기술연구소 주류분석 규정(NTS Liquors Licence Aid Center, 2010a)에 따라 각 누룩에 $0.5 \% \mathrm{NaCl}$ 용액을 가하여 실온 $\left(20^{\circ} \mathrm{C}\right.$ 이하)에 서 3시간 침출시켜 여과 후 효소용액으로 하고, $\mathrm{pH} 5.0$ 으로 보완한 $1 \%$ 녹말용액을 기질용액으로 하였다. 녹말용액 10 $\mathrm{mL}$ 를 $40^{\circ} \mathrm{C}$ 에서 예열한 후 효소용액 $0.5 \mathrm{~mL}$ 를 작용시켜 작 용혼합용액 중에서 $0.5-1$ 분마다 $0.1 \mathrm{~mL}$ 씩 요오드용액 10 $\mathrm{mL}$ 에 가하고 녹말요오드 반응색조를 분광광도계(HP 8453, Hewlett Packard, CA, USA)로 비색하여 투과율(T)이 66\%가 되는 반응시간을 구하고, 비교용액은 물 $10 \mathrm{~mL}$ 에 효소액 0.5 $\mathrm{mL}$ 를 가한 후 $0.1 \mathrm{~mL}$ 를 요오드용액에 가한 것을 투과율(T) $100 \%$ 로 하였다. 종점 전후의 반응시간을 비례 계산하여 $\mathrm{T}(66 \%)$ 가 될 때까지의 시간을 측정하였으며, 액화력은 다음 식에 의해 계산하였다.

Dextrinogenic activity units $=10 \mathrm{~mL} \times 1 / 0.5 \times \frac{30}{\mathrm{~h}}$

$\mathrm{h}: \mathrm{T}$ 가 되는 반응시간(h)

누룩의 단백질 분해력(Protease 활성)은 Greenberg 개량법 (So, 1999)에 따라 $\mathrm{pH}$ 를 5 로 조정한 $0.6 \%$ casein 용액을 기 질로, 누룩의 침출액을 효소액으로 하여 $40^{\circ} \mathrm{C}$ 에서 10 분간 반 응시켰다. 이 때 생산되는 Folin 발색성 비단백성 물질의 양을 Folin 비색법(Folin과 Ciocalteau, 1927)으로 측정하여 누룩 1 $\mathrm{g}$ 이 1 분 동안 생성되는 tyrosine을 $\mathrm{mg}$ 으로 나타내었다.

\section{$\mathrm{pH}$, 적정산도 및 환원당 함량 측정}

$\mathrm{pH}$ 는 발효 중인 술덧 여액 $20 \mathrm{~mL}$ 를 취하여 $\mathrm{pH}$ meter (HM-40X, DKK-TOA, Tokyo, Japan)를 사용해 측정하였고, 적정산도는 시료 $1 \mathrm{~mL}$ 에 증류수 $9 \mathrm{~mL}$ 를 가한 후 혼합하여 희석시킨 뒤 $1 \%$ phenolphthalein 용액을 지시약으로 하여
$0.1 \mathrm{~N} \mathrm{NaOH}$ 용액으로 중화 적정시킨 후 0.009 를 곱하여 lactic acid로 환산하였다(Huh, 2006). 환원당 함량 변화는 Somogyi 변법(Hatanaka와 Kobara, 1990)에 준하여 측정하였 다. 즉, 시료 $10 \mathrm{~mL}$ 를 Somogyi 변법에 의해 정량하여 glucose 함량으로 표시하였다.

\section{에탄올 함량 측정}

에탄올 함량은 Lee 등(2019)의 방법에 따라 시료 $100 \mathrm{~mL}$ 를 취하여 증류수 약 $30 \mathrm{~mL}$ 를 혼합하고, $70 \mathrm{~mL}$ 를 증류한 다 음 증류수로 $100 \mathrm{~mL}$ 되게 정용한 후 Gay-Lussak의 주정환 산표(NTS Liquors Licence Aid Center, 2010b)로 주정분을 결정하였다.

\section{색도 측정}

색도 측정은 시료 일정량을 취해 색도계(super color sp-80, Tokyo, Denshoku, JAPAN)를 이용해 $\mathrm{X}=80.84, \mathrm{Y}=82.22$, $\mathrm{Z}=92.98$ 인 표준 백색판(standard white plate)으로 보정하여 사 용하였다. 측정값은 명도를 나타내는 L 값(lightness), 적색을 나타내는 a 값(redness) 및 황색을 나타내는 b 값(yellowness)으 로 나타내었다.

\section{유리당 및 유기산 분석}

유리당은 Wilson 등(1981)의 방법에 따라 분석하였다. 즉, 시료 $10 \mathrm{~mL}$ 를 취하여 $100 \mathrm{~mL}$ 로 정용한 다음 원심분리(300 $\mathrm{rpm}, 30 \mathrm{~min}$ )한 후 상등액을 취하여 $0.45 \mu \mathrm{m}$ membrane filter로 여과한 여액을 HPLC(1260 Series, Agilent Co., Darmstadt, Germany)를 이용하여 분석하였으며, column은 carbohydrate column(ID 4.6×2,500 mm, Alltech Co, MA, USA)를 사용하였으며, column oven 온도는 $30^{\circ} \mathrm{C}$, mobile phase는 acetonitile:water(75:25, v/v), flow rate는 $1.0 \mathrm{~mL} / \mathrm{min}$, detector는 ELSD 2000ES detector(Alltech Co, MA, USA)를 사용하였고, 함량은 외부표준법으로 계산하였다. 유기산은 Gancedo와 Luh(1986)의 방법에 따라 시료를 전처리하여 HPLC(Waters M510, Waters Co., Milford, MA, USA)로 분 석하였고, column은 organic acid column(ID $4.6 \times 250 \mathrm{~mm}$, Grace Co., Deerfiled, IL, USA)를 사용하였으며, mobile phase는 $0.2 \mathrm{mM} \mathrm{KH}_{2} \mathrm{PO}_{4}$, flow rate는 $1.0 \mathrm{~mL} / \mathrm{min}$, detector 는 $\mathrm{DAD}(1100$ Series, Agilent Co., CA, USA)를 사용하였고, 함량은 외부표준법으로 나타내었다.

\section{총폴리페놀 및 총플라보노이드 분석}

총폴리페놀 함량은 Folin-Denis법(Florence 등, 1992)에 준 하여 측정하였다. 증류수로 희석한 시료추출물 $2 \mathrm{~mL}$ 에 $5 \%$ $\mathrm{NaCO}_{3} 5 \mathrm{~mL}$ 를 혼합한 뒤 3분 방치 후 Folin-Denis regent 
$2 \mathrm{~mL}$ 를 혼합하고 1시간 방치한 다음 분광광도계(HP 8453, Hewlett Packard)를 이용해 $660 \mathrm{~nm}$ 에서 흡광도를 측정하였 으며, 표준물질로는 tannic acid를 사용하였다. 총플라보노이 드 함량은 Davis변법(Chang 등, 2002)에 따라 측정하였다. 시료 추출물 $1 \mathrm{~mL}$ 에 diethylene glycol $10 \mathrm{~mL}$ 와 $1 \mathrm{~N} \mathrm{NaOH}$ $1 \mathrm{~mL}$ 를 혼합한 뒤 $30^{\circ} \mathrm{C}$ 에서 60 분간 유지시킨 다음 $420 \mathrm{~nm}$ 에서 흡광도를 측정하였다. Quercetin의 검량선을 이용하여 플라보노이드 함량을 계산하였다.

\section{$\mathrm{DPPH}$ 자유 라디칼 소거활성 측정}

$\mathrm{DPPH}$ 자유 라디칼 소거활성은 Blois의 방법(Abe 등, 2000)에 따라 시료의 1,1-diphenyl-2-picryl-hydrazyl(DPPH) 에 대한 수소공여 효과로 측정하였다. 일정 농도의 시료 2 $\mathrm{mL}$ 에 $2 \times 10^{-4} \mathrm{M} \mathrm{DPPH}$ 용액(dissolved in $99 \%$ methanol)을 1 $\mathrm{mL}$ 첨가하고, vortex mixing하여 $37^{\circ} \mathrm{C}$ 에서 30 분간 반응시켰 다. 이 반응액을 분광광도계(HP 8453, Hewlett Packard)를 사용하여 $517 \mathrm{~nm}$ 에서 흡광도를 측정하였고 (A control - A sample/ A control × 100)으로 계산하여 전자공여능(electron donating ability, $\mathrm{EDA}(\%)$ 으로 표시하였다.

\section{$\mathrm{ABTS}$ 자유 라디칼 소거활성 측정}

$\mathrm{ABTS}$ 자유 라디칼 소거활성은 과황산칼륨의 반응에 의해 생성된 ABTS radical이 시료내의 항산화 물질에 의해 제거 되면서 청록색으로 탈색되는 것을 이용한 방법이다(Park 등, 2019). $7 \mathrm{mM} \mathrm{ABTS}$ 용액과 $2.4 \mathrm{mM}$ 과황산칼륨을 혼합하여 암소에서 24시간 동안 반응시켜 $\mathrm{ABTS}^{+}$- 용액을 형성시킨 후 $734 \mathrm{~nm}$ 에서 흡광도 값이 $0.70 \pm 0.02$ 가 되게 증류수로 희석 하였다. 희석된 용액과 각 추출물을 $1: 1$ 로 혼합 후 분광광도계 (HP 8453, Hewlett Packard)를 이용해 $734 \mathrm{~nm}$ 에서 흡광도를 측정하였으며, [(A control - A sample $) / \mathrm{A}$ control $\times 100)]$ 으 로 계산하여 ABTS scavenging ability(\%)를 나타내었다.

\section{관능평가}

관능평가는 시료준비, 제시순서, 평가 방법 등이 가능한 동
일한 조건으로 진행될 수 있도록 하였다. 순천대학교 식품공 학과에 재학 중인 학생 10 명을 대상으로 백미. 유색미 쌀가루 개량누룩을 첨가한 약주를 9점 척도법 1 ; 대단히 싫음, 9 ; 대 단히 좋음)으로 평가하여 색, 향, 맛, 전체적인 기호도에 대한 평가를 실시했다(순천대학교 생명윤리위원회 승인번호: 104 0173-201907-HR-020-02).

\section{통계분석}

실험결과는 3 회 반복 측정한 후 SPSS program( $25, \mathrm{IBM}$ Corp., Armonk, NY, USA)을 사용하여 mean $\pm \mathrm{SD}$ 를 구하였 으며, Duncan's multiple range test로 시료간의 유의차를 분 석하였다. 독립된 두 집단의 평균값 비교는 두 표본 t-검정 (two sample t-test)을 이용하여 집단 간의 차이를 분석하였 다.

\section{결과 및 고찰}

\section{누룩의 효소활성( $\beta$-amylase, $\alpha$-amylase, protease)}

본 연구에서는 기존에 사용해오던 누룩의 복잡한 제조 공 정을 보다 간편하고 손쉽게 제조하는 방법을 연구하였고, 제조 한 누룩의 품질을 평가하였다. 쌀가루 개량누룩의 $\beta$-amylase 활성, $\alpha$-amylase 활성 및 protease 활성도를 측정한 결과는 Table 1과 같다. $\beta$-Amylase 활성과 protease 활성도에서 유색 미 쌀가루 개량누룩이 $1,186.67 \mathrm{SP} / \mathrm{g}, 378.90$ tyrosine $\mathrm{mg} / \mathrm{min}$ 으로 백미 쌀가루 개량누룩보다 높았고, $\alpha$-amylase 활성은 백미 쌀가루 개량누룩이 280.00 A.U로 유색미 쌀가루 개량 누룩보다 높은 값을 보였다. 누룩 제조 시 효소활성은 당화효 소뿐만 아니라, 생전분 분해효소의 역할로도 중요하다(Choi 등, 2011). 술을 발효시키기에 적합한 누룩의 $\beta$-amylase 활성 은 $300 \mathrm{sp}$ 이상으로 국세청 주류분석규정에 명시되어 있다 (NTS Liquor Licence Aid center, 2010c). 이는 쌀가루 개량 누룩이 기존의 누룩들과 비교하였을 때 높은 효소활성을 보 여 충분한 활용가치가 있을 것으로 판단된다.

Table 1. Enzymic activity of white rice flour 'Nuruk' and pigmented rice flour 'Nuruk'

\begin{tabular}{cccc}
\hline Enzymic activity & Saccharogenic activity (SP/g) & Dextrinogenic activity (A.U) & Proteolytic activity (tyrosine mg/min) \\
\hline WN $^{1)}$ & $1,160.00 \pm 20.00^{2)}$ & $280.00 \pm 34.64$ & $316.08 \pm 0.89$ \\
PN & $1,186.67 \pm 11.55$ & $266.67 \pm 57.74$ & $378.90 \pm 4.29$ \\
t-value & 2.000 & 0.343 & -24.844 \\
p-value & 0.561 & 0.242 & $0.042^{* 3)}$ \\
\hline
\end{tabular}

${ }^{1)} \mathrm{WN}$, white rice flour 'Nuruk'; PN, pigmented rice flour 'Nuruk'.

2) All values are mean $\pm \mathrm{SD}(\mathrm{n}=3)$.

${ }^{3)} \mathrm{p}<0.5$. 


\section{$\mathrm{pH}$ 및 적정산도}

발효기간에 따른 백미, 유색미 쌀가루 누룩 첨가 약주의 $\mathrm{pH}$ 및 적정산도를 측정한 결과는 Fig. 3 및 Fig. 4와 같다. 담금 직후의 $\mathrm{pH}$ 는 유색미 쌀가루 누룩 첨가 약주가 4.77 , 백 미 쌀가루 누룩 첨가 약주가 4.82였고, 유색미 쌀가루 누룩 첨가 약주는 발효 3일째에 4.58로 소폭 감소 후 그 값을 유지 하였다. 백미 쌀가루 누룩 첨가 약주는 발효 3 일에 3.90 의 값 으로 낮은 값을 보이다 발효 완료 때까지 증가하였다. 발효 초기에 $\mathrm{pH}$ 가 감소하는 경향은 본격적으로 발효가 진행됨에 따라 술덧에 생육하는 미생물의 작용으로 유기산의 생성량이 증가되어 $\mathrm{pH}$ 가 저하된다(Song등, 1997). 유색미 쌀가루 누룩 첨가 약주의 경우, 발효 초기의 $\mathrm{pH}$ 에 변화가 백미 쌀가루 누 룩 첨가 약주보다 적었는데, 이는 유색미 쌀가루 누룩 첨가

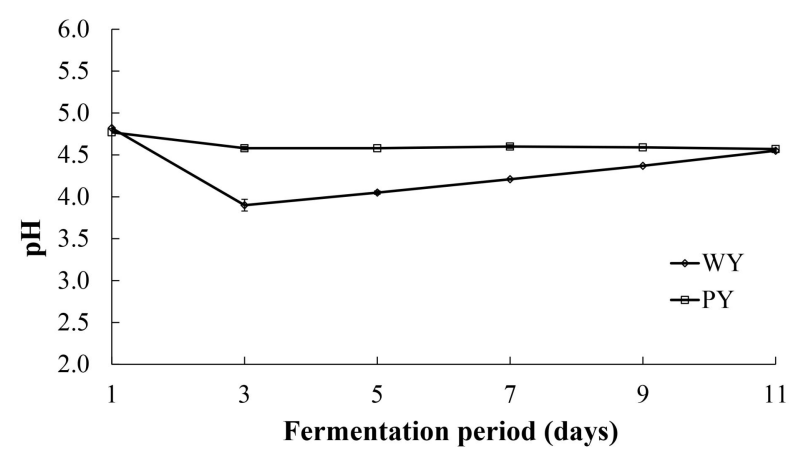

Fig. 3. Changes in $\mathrm{pH}$ of 'Yakju' made with white rice flour 'Nuruk' or pigmented rice flour 'Nuruk' during fermentation period.

WY, 'Yakju' made with white rice flour 'Nuruk'; PY, 'Yakju' made with pigmented rice flour 'Nuruk'.

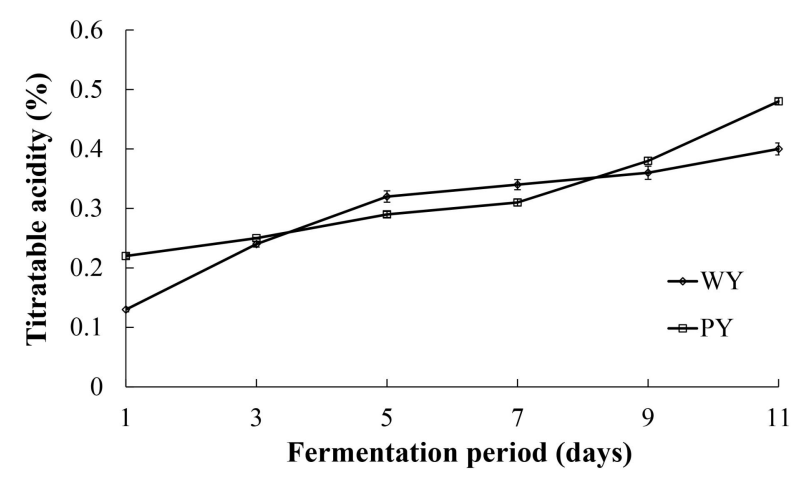

Fig. 4. Changes in titratable acidity of 'Yakju' made with white rice flour 'Nuruk' or pigmented rice flour 'Nuruk' during fermentation period.

WY, 'Yakju' made with white rice flour 'Nuruk'; PY, 'Yakju' made with pigmented rice flour 'Nuruk'.
약주의 발효가 발효 시작시점부터 발효 1 일째의 24 시간 동안 왕성하게 일어나서 나타난 결과로 판단된다. Cheong 등 (2008)은 올방개를 이용한 약주의 품질특성에서 약주의 $\mathrm{pH}$ 를 확인한 결과, $3.60-5.00$ 이었다고 보고하여 본 실험에서 제 조한 약주의 $\mathrm{pH}$ 와 유사한 경향이었다. 발효기간에 따른 적정 산도의 값은 두 샘플 모두 점차 증가하는 경향을 보였으며, 11 일 째 $0.40-0.48 \%$ 의 함량을 가졌다. 이는 국립농산물품질 관리원의 술 품질인증기준(NAQS, 2013)에서 고시한 적정산 도 기준인 $0.5 \%$ 이하에 충족하는 것으로 나타났다. 약주의 주원료인 쌀의 발효 작용으로 인해 생성되는 유기산은 약주 의 감미와 산미에 영향을 주는 주요 성분으로 본 실험의 결 과, 유색미 쌀가루 개량누룩 첨가 약주가 산도가 높게 나타나 유색미로 약주를 제조하였을 때 감미와 산미에 좋은 영향을 끼칠 것으로 판단된다(Jin 등, 2008).

\section{환원당 함량}

발효기간에 따른 약주의 환원당 함량의 변화는 Fig. 5 와 같다. 환원당은 보통 술 제조 시 당화과정을 거치며 전분으로 부터 유리되고, 유리된 당은 효모에 의하여 알코올과 이산화 탄소를 생성하게 된다. 전분의 당화로 인해 발효 3 일차에 백 미, 유색미 쌀가루 개량 누룩 첨가 약주는 $14.5 \%, 14.8 \%$ 를 보였으며, 이 후 알코올 발효가 진행됨에 따라 급격히 감소하 였다. Park 등(2004)에 의하면 발효 초기 당화효소 작용이 알 코올 발효과정보다 높아 과량의 환원당이 생성되었다고 보고 한 결과와 유사한 경향을 나타내었다. 이러한 발효 형태를 고 려할 때 당 함량과 알코올 함량은 상당한 연관성을 갖는다고 할 수 있으며, 본 연구 결과에서도 비슷한 발효 형태로 진행 되었다고 판단된다(Sin 등, 2016a).

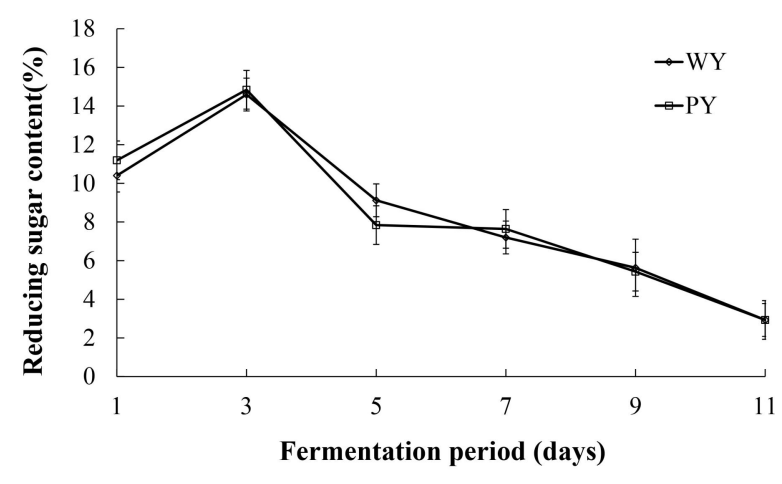

Fig. 5. Changes in reducing sugar content of 'Yakju' made with white rice flour 'Nuruk' or pigmented rice flour 'Nuruk' during fermentation period.

WY, 'Yakju' made with white rice flour 'Nuruk'; PY, 'Yakju' made with pigmented rice flour 'Nuruk'. 


\section{에탄올 함량}

백미와 유색미 쌀가루 누룩 첨가 약주의 에탄올 함량을 측 정한 결과는 Fig. 6 과 같다. 에탄올 함량은 술의 보존성이나 향미에 영향을 주는 중요한 성분으로 에탄올 발효는 당을 에 탄올과 $\mathrm{CO}_{2}$ 로 분해한 것이다(Lee 등, 2019). 발효기간에 따 른 에탄올 함량의 변화를 확인한 결과, 발효 5 일째에 알코올 함량이 급격하게 증가하여 유색미 쌀가루 누룩을 첨가한 약 주와 백미 쌀가루 누룩을 첨가한 약주가 $13.43 \%$ 와 $13.23 \%$ 의 값을 보였으며, 유의적 차이를 나타내지 않았다. 하지만 발효 11 일째에는 유색미 쌀가루 누룩을 첨가한 약주가 $14.6 \%$ 로 백미 쌀가루 누룩을 첨가한 약주(13.5\%)에 비해 높은 함 량을 보였다. 앞서 환원당 함량을 측정한 결과, 발효 11 일차 에 환원당 함량이 유의적인 차이가 없었으나 에탄올 함량은 발효 11 일차에 약 $1 \%$ 내외의 차이를 보였다. 술은 제조시에 이상 발효가 진행되거나 산화로 인해서 에탄올 성분 감소가 일어날 수 있다(Jeong 등, 2013). 본 연구 결과에서도 그러한 이유로 약간의 차이가 발생한 것으로 판단된다. 에탄올은 약 주의 보존성이나 향미에 영향을 주는 중요한 성분으로 술의 에탄올 함량은 다소 높아야 한다고 보고되어 있다(Jin 등, 2006). 따라서 에탄올 함량이 좀 더 높았던 유색미 개량누룩 을 첨가한 약주가 백미 개량누룩을 첨가한 약주보다 보존성 과 맛에 좋은 영향을 끼칠 것으로 예상된다. 또한, Cho 등 (2016)은 여주 분말 쌀누룩으로 제조한 막걸리의 에탄올 함 량이 더 높은 것으로 보고되었으며, Joo 등(2010)은 흑미를 이용한 전통주 제조에서 흑미가 백미보다 알코올분이 약 $0.4 \%$ 높게 측정되었다고 보고되어 본 연구와 유사한 결과를 나타내었다.

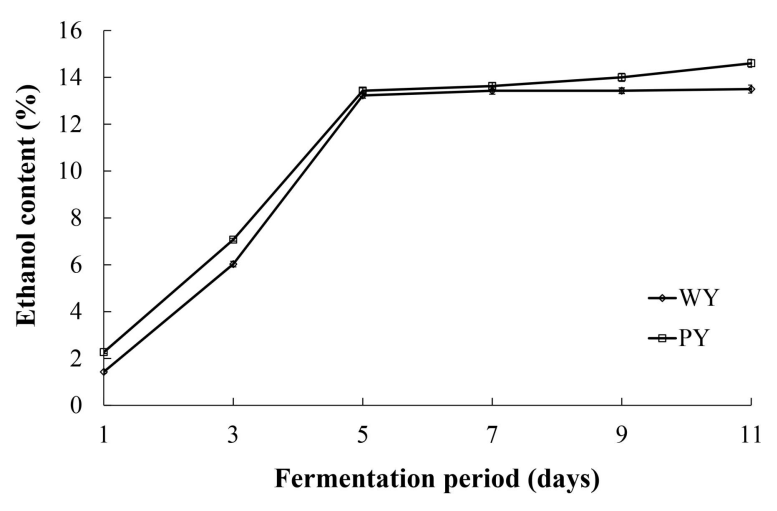

Fig. 6. Changes in ethanol content of 'Yakju' made with white rice flour 'Nuruk' or pigmented rice flour 'Nuruk' during fermentation period.

WY, 'Yakju' made with white rice flour 'Nuruk'; PY, 'Yakju' made with pigmented rice flour 'Nuruk'.
색도

약주의 색도를 측정 결과, Table 2에서 보는 바와 같이 백 미 쌀가루 누룩을 첨가한 약주의 경우 L값(lightness)은 발효 가 진행될수록 떨어져 68.06 을 나타내었고, b값(yellowness) 은 5.62에서 7.64로 증가하였다. 유색미 쌀가루 개량누룩을 첨가한 약주 또한 명도를 나타내는 $\mathrm{L}$ 값이 발효완료 시점에 서 43.84를 나타내었으며, $\mathrm{a}$ 값(redness), $\mathrm{b}$ 값은 증가하여 $19.29,21.41$ 의 값을 보였다. 발효기간 동안 L값은 점차 떨어 졌고, $\mathrm{b}$ 값은 증가하는 것으로 보아 약주에 함유되어 있는 플 라보노이드 성분이 발효 중 서서히 산화되어 $\mathrm{b}$ 값이 증가하 는 것으로 판단된다(Choi 등, 2013). 또한 a값은 백미 약주보 다 유색미 약주가 약 15-20배 정도 높게 나타났다. 이는 유색 미 약주의 a값은 유색미 자체에 함유되어 있는 안토시아닌 색소성분에 의해서 높게 나타난 것으로 판단된다. 유색미 약 주의 발효기간에 따른 a값은 발효기간이 경과할수록 증가하 는 경향을 보였는데, 이는 발효가 진행되면서 안토시아닌 색 소 용출이 증가하면서 값이 증가하는 것으로 판단된다 $(\mathrm{Kim}$ 등, 2012).

\section{유리당 및 유기산 함량}

약주의 감미는 주로 전분 분해에 의해 생성된 glucose에서 기인하며, 발효 과정 중 유리당 함량의 변화는 담금 방법이나 전분질 원료와 누룩에 따라 차이를 나타낸다(Jeong 등, 2006). 쌀가루 개량누룩을 첨가한 약주의 유리당 함량 및 조성을 분 석한 결과는 Table 3 과 같다. 확인된 유리당은 glucose와 maltose 두 종류가 정량되었으며, 전반적으로 glucose의 함량 이 $119.12 \mathrm{mg} \%, 190.03 \mathrm{mg} \%$ 수준으로 검출되었다. Kim과 $\mathrm{Koh}(2004)$ 가 발표한 제주좁쌀약주의 품질개선을 위한 선발 균주에 의한 양조특성에서 glucose가 주요 유리당으로 보고되 었으며, Lee 등(2012)은 개량누룩으로 담근 막걸리의 glucose 함량이 유의적으로 많은 것으로 나타나 본 실험결과와 유사 하였다.

백미, 유색미 쌀가루 누룩을 첨가한 약주의 유기산 함량을 분석한 결과는 Table 3 과 같다. 유기산은 약주의 산미에 영향 을 주어 품질에 중요한 영향을 미친다. 발효 완료 후 총 유기 산 함량은 유색미 쌀가루 누룩을 첨가한 약주가 $1,225.87$ $\mathrm{mg} \%$ 의 함량을 나타내었다. 유기산 종류에 따른 함량은 succinic acid가 검출된 6종의 유기산류 중 가장 높은 비율을 차지하였고, lactic acid, oxalic acid, malic acid, acetic acid 및 citric acid가 검출되었다. 발효 대사로부터 생산되는 유기 산은 술에 있어서 상쾌한 맛을 내는 주체로 미량 존재할 경 우, 술의 맛과 향을 높이는 역할을 하지만, acetic acid가 다량 존재하면 알코올 성분이 산화되어 초산발효가 되므로 질을 저하시키는 요인이 된다(Baek 등, 2013). 백미, 유색미 쌀가 
Table 2. Changes in color of 'Yakju' made with white rice flour 'Nuruk' or 'Yakju' made with pigmented rice flour 'Nuruk' during fermentation period

\begin{tabular}{|c|c|c|c|c|}
\hline \multirow{2}{*}{ Sample } & \multirow{2}{*}{$\begin{array}{l}\text { Fermentation } \\
\text { (days) }\end{array}$} & \multicolumn{3}{|c|}{ Color } \\
\hline & & $\mathrm{L}$ & $\mathrm{a}$ & $\mathrm{b}$ \\
\hline \multirow{6}{*}{$W Y^{1)}$} & 1 & $86.46 \pm 0.00^{2) b 33}$ & $1.00 \pm 0.01^{\mathrm{h}}$ & $5.62 \pm 0.00^{1}$ \\
\hline & 3 & $87.52 \pm 0.01^{\mathrm{a}}$ & $0.47 \pm 0.05^{\mathrm{j}}$ & $6.00 \pm 0.01^{\mathrm{k}}$ \\
\hline & 5 & $81.98 \pm 0.02^{\mathrm{c}}$ & $0.95 \pm 0.05^{\mathrm{hi}}$ & $6.61 \pm 0.03^{\mathrm{i}}$ \\
\hline & 7 & $79.12 \pm 0.01^{\mathrm{e}}$ & $1.02 \pm 0.08^{\mathrm{g}}$ & $6.53 \pm 0.01^{j}$ \\
\hline & 9 & $79.94 \pm 0.02^{\mathrm{d}}$ & $0.85 \pm 0.07^{\mathrm{i}}$ & $7.32 \pm 0.02^{\mathrm{h}}$ \\
\hline & 11 & $68.06 \pm 0.04^{\mathrm{j}}$ & $1.84 \pm 0.04^{\mathrm{f}}$ & $7.64 \pm 0.03^{\mathrm{g}}$ \\
\hline \multirow{6}{*}{ PY } & 1 & $72.95 \pm 0.13^{\mathrm{f}}$ & $14.96 \pm 0.16^{\mathrm{e}}$ & $16.30 \pm 0.02^{\mathrm{e}}$ \\
\hline & 3 & $71.27 \pm 0.02^{\mathrm{g}}$ & $15.02 \pm 0.02^{\mathrm{e}}$ & $16.37 \pm 0.05^{\mathrm{d}}$ \\
\hline & 5 & $70.81 \pm 0.03^{\mathrm{h}}$ & $16.77 \pm 0.03^{\mathrm{b}}$ & $17.04 \pm 0.02^{b}$ \\
\hline & 7 & $71.26 \pm 0.01^{\mathrm{g}}$ & $16.16 \pm 0.02^{\mathrm{d}}$ & $16.15 \pm 0.05^{\mathrm{f}}$ \\
\hline & 9 & $68.45 \pm 0.01^{\mathrm{i}}$ & $16.27 \pm 0.06^{\mathrm{c}}$ & $16.61 \pm 0.06^{\mathrm{c}}$ \\
\hline & 11 & $43.84 \pm 0.05^{\mathrm{k}}$ & $19.29 \pm 0.03^{\mathrm{a}}$ & $21.41 \pm 0.08^{\mathrm{a}}$ \\
\hline
\end{tabular}

${ }^{1)}$ WY, 'Yakju' made with white rice flour 'Nuruk'; PY, 'Yakju' made with pigmented rice flour 'Nuruk'.

${ }^{2)}$ All values are mean $\pm \mathrm{SD}(\mathrm{n}=3)$.

${ }^{3}$ Means in the same column followed by different uppercase letters are significantly different $(\mathrm{p}<0.05, a>b>c>d>e>f>g>h>i>j>k>1)$.

Table 3. The contents of free sugar and organic acid in 'Yakju' made with white rice flour 'Nuruk' or 'Yakju' made with pigmented rice flour 'Nuruk'

$(\mathrm{mg} \%)$

\begin{tabular}{|c|c|c|c|c|c|}
\hline \multicolumn{2}{|c|}{ Component } & $\mathrm{WY}^{1)}$ & PY & t-value & $\mathrm{p}$-value \\
\hline \multirow{2}{*}{ Free sugar } & Glucose & $119.12 \pm 9.23^{2)}$ & $190.03 \pm 15.90$ & 0.001 & 0.142 \\
\hline & Maltose & $\mathrm{ND}^{3)}$ & $15.98 \pm 2.08$ & - & - \\
\hline \multicolumn{2}{|c|}{ Total } & 119.12 & 206.01 & & \\
\hline \multirow{6}{*}{ Organic acid } & Oxalic acid & $79.19 \pm 25.77$ & $75.82 \pm 2.70$ & 0.226 & $0.024^{* 4}$ \\
\hline & Malic acid & $143.28 \pm 10.67$ & $61.65 \pm 4.41$ & 12.241 & 0.135 \\
\hline & Lactic acid & $105.76 \pm 19.03$ & $148.11 \pm 1.37$ & -3.844 & 0.053 \\
\hline & Acetic acid & $252.41 \pm 23.93$ & $304.73 \pm 12.97$ & -3.330 & 0.214 \\
\hline & Citric acid & $122.32 \pm 5.63$ & $91.22 \pm 35.65$ & 1.492 & $0.030^{*}$ \\
\hline & Succinic acid & $318.72 \pm 41.71$ & $544.34 \pm 2.63$ & -9.350 & $0.020^{*}$ \\
\hline \multicolumn{2}{|c|}{ Total } & $1,021.69$ & $1,225.87$ & & \\
\hline
\end{tabular}

${ }^{1)} \mathrm{WY}$, 'Yakju' made with white rice flour 'Nuruk'; PY, 'Yakju' made with pigmented rice flour 'Nuruk'.

${ }^{2)}$ All values are mean \pm SD $(n=3)$.

${ }^{3)}$ Not detected.

$\left.{ }^{4}\right)^{*}<0.05$.

루 개량누룩을 첨가한 약주의 유기산을 측정한 결과, acetic acid 함량이 소량 검출되어 품질 저하는 적을 것으로 판단된 다. Lactic acid 함량은 유색미 쌀가루 개량누룩 첨가 약주가
백미 쌀가루 누룩 첨가 약주보다 높게 검출되었는데, 이 lactic acid 성분은 청량감을 주고 갈증을 해소해주는 유기산 으로 알려져 있다(Folin과 Ciocalteau, 1927). 


\section{총폴리페놀 및 총플라보노이드 함량}

폴리페놀 화합물은 식물계에 널리 분포되어 있는 2차 대사 산물의 하나로 ROS에 의한 세포 수준이나 DNA 등의 손상 을 억제하기 위한 방어 메커니즘을 제공한다고 알려져 있다 (Voya 등, 1997). 본 연구에서는 phenol성 물질인 tannic acid 와 quercetin을 기준으로 하여 실험구에 대한 총 폴리페놀과 총플라보노이드 함량을 알아보고자 하였으며, 그 결과는 Table 4에 나타내었다. 유색미 약주의 총폴리페놀 함량은 $35.96 \mathrm{mg} \%$ 로 백미 약주의 $16.29 \mathrm{mg} \%$ 와 비교하여 유의적 으로 높았으며, 총플라보노이드 함량 역시 $19.01 \mathrm{mg} \%$ 로 대 조군의 $6.36 \mathrm{mg} \%$ 보다 3 배 가량 높은 함량을 보였다. 유색미 는 플라보노이드 성분이 다량으로 함유되어 있는 원료로 알 려져 있으며, Yang 등(2015)은 유색미를 사용해 식혜를 제조 하여 기능성을 확인한 결과, 대조군보다 유색미를 이용한 식 혜가 높은 함량은 보였다고 보고하였고, 이 결과는 본 연구와 유사한 결과를 나타내었다.

\section{$\mathrm{DPPH}$ 자유 라디칼 소거 활성}

백미, 유색미 쌀가루 누룩을 이용한 약주의 DPPH 라디칼 소거활성을 측정한 결과는 Fig. 7과 같다. 유색미 쌀가루 개량 누룩을 첨가한 약주가 positive control인 vitamin $\mathrm{C}(85.15 \%)$ 에 비교하였을 때 DPPH radical을 $74.29 \%$ 정도 소거하였다. $\mathrm{DPPH}$ 는 분자 내에 위치한 안정한 라디칼을 함유하지만, 항 산화 활성이 있는 물질과 만나면 라디칼이 소거되며, 이때의 활성은 $\cdot \mathrm{OH}$ 와 유사하기 때문에 시료의 전자 공여능력을 측 정하는 방법으로 널리 쓰이고 있다(Molyneux, 2004). Ryu 등(2007)은 시판 전통주의 DPPH 자유라디칼 제거 활성을 분석한 결과, 활성이 낮다고 보고해, 기능성이 향상된 약주 개발이 필요한 실정으로 본 연구에서의 유색미를 활용한 약 주 개발은 사회적 요구에 부합된다고 판단된다.

\section{ABTS 자유 라디칼 소거 활성}

쌀가루 누룩을 이용한 약주의 ABTS 라디칼 소거활성을 측정한 결과는 Fig. 8 과 같다. 유색미 쌀가루 개량누룩을 첨 가한 약주가 $82.42 \%$ 로 백미 쌀가루 개량누룩을 첨가한 약주

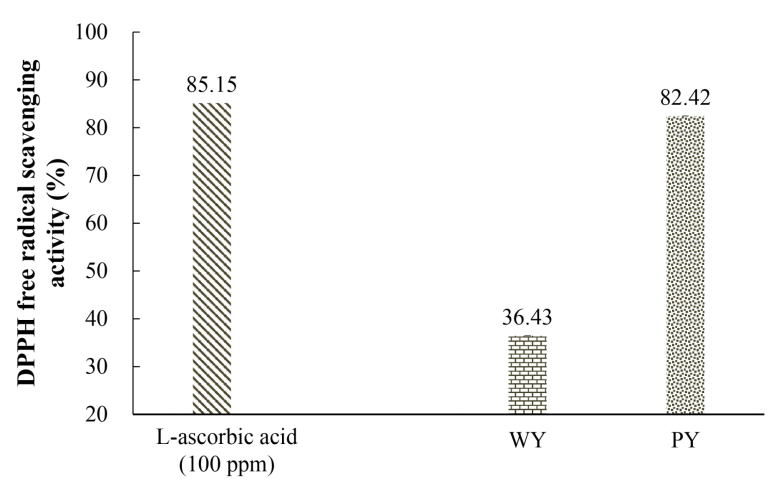

Fig. 7. DPPH free radical scavenging activity of 'Yakju' made with white rice flour 'Nuruk' or pigmented rice flour 'Nuruk'.

WY, 'Yakju' made with white rice flour 'Nuruk'; PY, 'Yakju' made with pigmented rice flour 'Nuruk'.

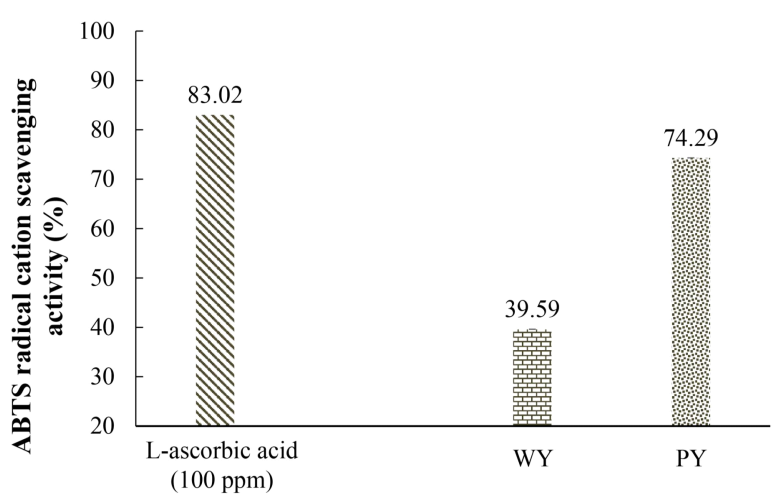

Fig. 8. ABTS radical cation scavenging activity of 'Yakju' made with white rice flour 'Nuruk' or 'Yakju' made with pigmented rice flour 'Nuruk' during fermentation period.

WY, 'Yakju' made with white rice flour 'Nuruk'; PY, 'Yakju' made with pigmented rice flour 'Nuruk'.

보다 ABTS 라디칼 소거능이 높은 항산화 활성을 보였다. Cho 등(2016)과 Song 등(2015)은 여주, 자색고구마, 오미자 등을 술에 첨가하였을 때 항산화 활성이 향상된 결과를 나타 내었으며, 본 실험에서 유색미를 첨가한 약주 또한 백미를 첨

Table 4. The contents of total polyphenolics and flavonoid in 'Yakju' made with white rice flour 'Nuruk' or 'Yakju' made with pigmented rice flour 'Nuruk'

$(\mathrm{mg} \%)$

\begin{tabular}{ccccc}
\hline Component & WY & PY & t-value & p-value \\
\hline Total polyphenols & $16.29 \pm 0.17^{2)}$ & $35.96 \pm 0.40$ & $0.253^{* 3)}$ & 2.911 \\
Total flavonoids & $6.36 \pm 1.26$ & $19.01 \pm 2.73$ & $0.163^{*}$ & 1.779 \\
\hline
\end{tabular}

${ }^{1)} \mathrm{WY}$, 'Yakju' made with white rice flour 'Nuruk'; PY, 'Yakju' made with pigmented rice flour 'Nuruk'.

2) All values are mean \pm SD $(n=3)$.

$3)^{*} \mathrm{p}<0.5$. 
가한 약주보다 항산화활성이 향상된 결과를 보였다. 이를 보 았을 때 유색미로 약주를 제조하였을 때보다 높은 기능성을 함유한 새로운 약주의 개발이 기대될 것으로 사료된다.

\section{관능평가}

쌀가루 개량누룩을 첨가 후 11 일 발효한 약주의 관능평가 결과는 Table 5 와 같다. 색은 유색미 쌀가루 개량누룩 첨가 약주가 백미 쌀가루 개량누룩 첨가 약주보다 높은 기호도를 보였으며, 이는 유색미의 적색도가 큰 영향을 미쳤을 것으로 사료된다. 풍미, 맛, 전체적 기호도 또한 유색미 쌀가루누룩 첨가 약주를 더욱 선호하는 결과를 보였다. 유색미 약주의 유 리당을 측정한 결과, 백미 약주에 비해 유색미 약주가 더 높 은 유리당을 보였는데, 이는 맛과 전체적 기호도에서 좋은 영 향을 끼친 것으로 판단된다. 식품에서 제품의 품질을 결정하 는 중요한 관능적 요소로는 일반적으로 색, 향미 및 맛 등을 들 수 있으며, 본 연구 결과 유색미 쌀가루 개량누룩을 첨가 한 약주의 색, 향미 및 맛에 대한 기호성이 높아 우리나라 약 주 제품의 품질을 증진시킬 수 있을 것으로 보여진다.

\section{요 약}

본 연구에서는 유색미를 이용하여 새로운 공정의 누룩을 제조하여 간편한 기술을 개발함과 동시에 유색미를 이용한 품질이 개선되고, 기능성이 향상된 약주를 개발하고자 하였 다. 누룩의 효소활성을 비교한 결과, 유색미 쌀가루 개량누룩 이 $\beta$-amylase 활성과 protease 활성도에서 유색미 쌀가루 개 량누룩이 $1,186.67 \mathrm{SP} / \mathrm{g}, 378.90$ tyrosine $\mathrm{mg} / \mathrm{min}$ 으로 백미 쌀가루 개량누룩보다 높은 효소 활성을 나타내었다. 제조된 쌀가루 개량누룩을 첨가한 약주의 품질특성에서 $\mathrm{pH}$ 의 경우 백미 쌀가루 누룩 첨가 약주는 발효 3일에 3.90으로 감소하 였으나, 점차 증가하는 경향을 보였다. 그에 비해 유색미 쌀 가루 누룩 첨가 약주는 발효 3 일에 4.58 로 발효 완료 때까지 차이를 보이지 않았다. 적정 산도는 유색미 쌀가루 누룩 첨가 약주가 백미 쌀가루 누룩 첨가 약주에 비해 높은 값을 나타내
었으며, 발효 완료 시점에서 $0.48 \%$ 였다. 환원당은 두 시료구 모두 3 일째에 높은 함량을 보이다 점차 줄어드는 경향을 보 였다. 에탄올 함량은 유색미 쌀가루 누룩 첨가 약주가 $14.6 \%$ 로 높은 함량을 나타냈다. 유리당은 glucose와 maltose 두 종 류가 검출되었고 glucose가 주를 이루었다. 유기산의 경우, 유 색미 쌀가루 누룩 첨가 약주가 총 $1,225.87 \mathrm{mg} \%$ 의 양으로 검출되었다. $\mathrm{DPPH}$ 라디칼 소거활성 및 $\mathrm{ABTS}$ 라디칼 소거 활성은 유색미 쌀가루 누룩을 첨가한 약주가 백미 쌀가루 누 룩 첨가 약주보다 2 배 정도 높은 값을 보였으며, 총폴리페놀 및 총플라보노이드 함량 역시 $35.96 \mathrm{mg} \%, 19.01 \mathrm{mg} \%$ 로 더 높은 값을 나타냈다. 관능평가 결과, 색, 향, 맛, 전체적 기호 도에서 유색미 쌀가루 누룩을 첨가한 약주가 더욱 높은 기호 도를 나타내었다. 이와 같은 결과를 토대로 유색미 쌀가루 개 량누룩을 첨가한 약주가 품질뿐만 아니라, 기능성이 개선된 약주로서 충분한 가치가 있을 것으로 판단된다.

\section{감사의 글}

본 연구는 농촌진흥청 산학연협력 광역화사업(2019-0172) 전남농업기술원 쌀산학연협력단의 연구비 지원을 받아 실행 한 결과의 일부로 이에 감사드립니다.

\section{Conflict of interests}

The authors declare no potential conflict of interest.

\section{ORCID}

Hong Bi Han https://orcid.org/0000-0003-4886-7570

Chang Ki Huh https://orcid.org/0000-0003-4456-8477

\section{References}

Abe N, Nemoto A, Tsuchiya Y, Hojo H, Hirota A. Studies

Table 5. The sensory scores on preperence of 'Yakju' made with white rice flour 'Nuruk' or 'Yakju' made with pigmented rice flour 'Nuruk'

\begin{tabular}{ccccc}
\hline Sample & WY $^{1)}$ & PY & t-value & p-value \\
\hline Color & $6.36 \pm 1.86^{2)}$ & $6.91 \pm 1.81$ & -0.697 & 0.283 \\
Flavor & $4.73 \pm 1.62$ & $5.27 \pm 2.05$ & -0.692 & 0.275 \\
Taste & $3.73 \pm 2.33$ & $4.36 \pm 2.62$ & -0.602 & 0.742 \\
Overall preference & $4.45 \pm 1.86$ & $4.91 \pm 2.43$ & -0.493 & 0.237 \\
\hline
\end{tabular}

${ }^{1)}$ WY, 'Yakju' made with white rice flour 'Nuruk'; PY, 'Yakju' made with pigmented rice flour 'Nuruk'.

${ }^{2)}$ All values are mean \pm SD $(n=3)$. 
on the 1,1-diphenyl-2-picrylhydrazyl radical scavenging mechanism for a 2-pyrone compound. Biosci Biotech Biochem, 64, 306-313 (2000)

Baek SY, Kim JY, Baek CH, Choi JH, Choi HS, Jeong ST, Yeo SH. Quality characteristics of Hwanggeumju as a traditional home-brewed liquor. Korean J Food Preserv, 20, 127-133 (2013)

Chang CC, Yang MH, Wen HM, Chern JC. Estimation of total flavonoid content in propolis by two complementary colorimetric methods. J Food Drug Anal, 10, 178-182 (2002)

Cheong C, Rhee IS, Lee SK, Kang SA. A study on the qualitative properties of traditional Sake using Allbanggae. J Korean Soc Food Sci Nutr, 37, 784-791 (2008)

Cho KM, Hwang CE, Lee HY, Ahn MJ, Joo OS. Quality characteristics and antioxidant activities of Makgeolli prepared using rice Nuruk containing bitter melon (Momordica charantia). Korean J Food Preserv, 23, 259-266 (2016)

Choi EY, Lee JT. The effects of antioxidant and anti-aging treatment of UVB-irradiated human HaCaT keratinocytes with ethanol extracts of colored rice varieties. Korean J Food Sci Technol, 50, 653-659 (2018)

Choi JS, Jung ST, Kim JY Choi JH, Choi HS, Yeo SH. Quality characteristics of wheat Nuruk and optimum condition of liquid starters for Aspergillus sp. Korean J Mucrobiol Biotechnol, 39, 357-363 (2011)

Choi JS, Yeo SH, Choi JH, Choi HS, Jeong ST. Quality properties of Jujube Yakju based on the adding rate of dried Jujube and storage periods. Korean J Food Preserv, 20, 52-61 (2013)

Folin O, Ciocalteau V. On tyrosine and tryptophane determination in proteins. J Biol Chem, 27, 627-650 (1927)

Forget FCR, Goupy P, Nicolas J. Cystenine as an inhibitor of enzymatic browing. 2. kinetic studies. J Agric Food Chem, 40, 2108-2113 (1992)

Gancedo MC, Luh BS. HPLC analysis of organic acids and sugar in tomato juice. J Food Sci, 51, 571-580 (1986)

Hatanaka C, Kobara Y. Determination of glucose by a modification of Somogyi-Nelson method. J Korean Soc Agric Chem, 44, 2943-2949 (1990)

Huh CK, Han HB, Lee CK, Jeong JH, Park SJ, Na JH, Kim CM, Jo SH. New technology of rice flour 'Nuruk'. Korea Patent No. 10-2018-0120039 (2018)
Huh CK, Han HB, Lee CK, Jeong JH, Park SJ, Na JH, Kim CM, Kim BS, Shin SH. A Nuruk prepared by Dahyangheungmi without cooking and fermented alchohol preparing therefor. Korea Patent No. 0131353 (2019)

Huh CK, Lee JW, Kim YD. Comparison of the organic acids, fusel oil contents and antioxidant activities of Yakju with the additions of various rice cultivars. Korean J Food Preserv, 20, 365-371 (2013)

Huh CK, Lee JW, Kim YD. Quality characteristics of rice wine according to the rice wine seed mash with lactic acid concentration. Korean J Food Preserv, 19, 933 (2012)

Huh CK. Effect of recipe for chestnut wine on fermentation and quality characteristics. Ms Thesis, Sunchon National University, Korea, p 50 (2006)

Jeong JW, Park KJ, Kim MH, Kim DS. Quality characteristics of Takju fermentation by addition of chestnut peel powder. Korean J Food Preserv, 13, 329-336 (2006)

Jeong ST, Kwak HJ, Kim SM. Quality chracteristics and biogenic amine production of Makgeolli brewed with commercial Nuruks. Korean J Food Sci Technol, 45, 727-734 (2013)

Jin TY, Chung HJ, Eun JB. The effect of fermentation temperature on the quality of Jinyangju, a Korean traditional rice wine. Korean J Food Sci Technol, 38, 414-418 (2006)

Jin TY, Lee WG, Lee IS, Wang MH. Changes of physicochemical, sensory and antioxidant activity characteristics in rice wine, Yakju added with different ratios of Codonopsis lanceolata. Korean J Food Sci Technol, 40, 201-206 (2008)

$\mathrm{Ju}$ YK. Development and quality feature of colored tradition wine fermented using black rice. Ms Thesis, Donga University, Korea, p 41-43 (2010)

Joo SY, Choi HY. Antioxidant activity and quality characteristics of black rice bran cookies. J Korean Soc Food Sci Nutr, 41, 182-191 (2012)

Kim JY, Koh JS. Fermentation characteristics of Jeju foxtail millet-wine by isolated alcoholic yeast and saccharifying mold. J Korean Soc Appl Biol Chem, 47, 85-91 (2004)

Kim MS, Hahn TR, Yoon HH. Saccarification and sensory characteristics of Sikhe made of pigmented rice. Korean J Food Sci Technol, 31, 672-677 (1999)

Kim OS, Park SS, Sung JM. Antioxidant activity and 
fermentation characteristics of traditional black rice wine. J Korean Soc Food Sci Nutr, 41, 1693-1700 (2012)

Lee CG, Na JH, Park SJ, Jeong JH, Kim CM, Kim BS, Han HB, Huh CK. Quality analysis of Makgeolli made with non-steamed rice flour Nuruk by various fungal strains. Korean J Food Preserv, 26, 496-504 (2019)

Lee DH, Kang HY, Yong SL, Cho CH, Kim SJ, Lee JS. Effects of yeast and Nuruk on the quality of Korean Yakju. Korean J Microbiol Biotechnol, 39, 274-280 (2011)

Lee YJ, Yi HC, Hwang KT, Kim DH, Kim HJ, Jung CM, Choi YH. The qualities of Makgeolli (Korean rice wine) made with different rice cultivars, milling degrees of rice, and Nuruks. J Korean Soc Food Sci Nutr, 41, 1785-1791 (2012)

Molyneux P. The use of the stable free radical diphenylpicrylhydrazyl (DPPH) for estimating antioxidant activity. Songklanakarin J Sci Technol, 26, 211-219 (2004)

NAQS Criteria of Alcohol Quality Certification. National Agricultural Products Quality Management Service Announcement, No. 2013-12 (2013)

NTS Liquors Licence Aid Center. Analysis of Alcoholic Beverages. National Tax Service, Seoul, Korea, p 12-16 (2010a)

NTS Liquors Licence Aid Center. Analysis of Alcoholic Beverages. National Tax Service, Seoul, Korea, p 40 (2010b)

NTS Liquors Licence Aid Center. Analysis of Alcoholic Beverages. National Tax Service, Seoul, Korea, p 79 (2010c)

Park JH, Baes SM, Yook C, Kim JS. Fermentation characteristics of Takju prepared with old rice. Korean J Food Sci Technol, 36, 609-615 (2004)

Park SJ, Na JH, Lee CG, Jeong JH, Kim CM, Han HB, Kim BS, Park CH, Huh CK. Quality characteristics of Tenebrio molitor L. ingested yuzu supplemented feed. Korean J Food Preserv, 26, 777-784 (2019)

Ryu HY, Kum EJ, Bae KH, Kim YK, Kwun IS, Sohn HY. Evaluation for the antimicrobial, antioxidant and antithrombosis activity of Korean traditional liquors. Kor $\mathbf{J}$
Microbiol Biotechnol, 35, 238-244 (2007)

Seo MJ, Ryu SR. Improvement of Cheongju manufacturing process using gelatinized rice and zeolite. Korean J Food Sci Technol, 34, 610-616 (2002)

Shin DS, Choi YJ, Jeong ST, Sim EY, Lee SK, Kim HJ, Woo KS, Kim SJ, Oh SK, Park HY. Quality characteristics of mixed Makgeolli with barley and wheat. Korean J Food Nutr, 29, 565-572 (2016a)

Shin DS, Yoo SM, Han GJ, Oh SG. Quality of Tteokbokki tteok prepared by adding various concentration of brown rice. Korean J Food Preserv, 23, 194-203 (2016b)

Sin EJ. Characteristics of rice sponge cakes and rice cookies prepared with pigmented rice varieties. Ph D Thesis, Sejong University, Korea, p 30-31 (2019)

Song JC, Park HJ, Shin WC. Changes of Takju qualities by addition of cyclodextrin during the brewing and aging. Korean J Food Sci Technol, 29, 895-900 (1997)

Song JY. Quality characteristics of Takju made of glutinous rice of barley. MS Thesis. Seoul Women's University, Korea (1998)

Song YR, Lim BU, Song GS, Baik SH. Quality characteristics and antioxidant activity of Makgeolli supplemented with Omija berries (Schizandra chinensis Baillon). Korean J Food Sci Technol, 47, 328-335 (2015)

Voya J, Belinky PA, Aviram M. Antioxidant constituents from licorice roots: Isolation, structure elucidation and antioxidative capacity toward LDL oxidation. Free Radic Biol Med, 23, 302-313 (1997)

Wilson AM, Work TM, Bushway AA, Bushway RJ. HPLC determination of fructose, glucose, and sucrose in potatoes. J Food Sci, 46, 300-301 (1981)

Woo SM, Shin JS, Seong JH, Yeo SH, Choi JH, Kim TY, Jeong YJ. Quality characteristics of brown rice Takju by different Nuruks. J Korean Soc Food Sci Nutr, 39, 301-307 (2010)

Yang JW, Kim YE, Lee KH. Physicochemical characteristics and antioxidant activities of Sikhye made with pigmented rice. J East Asian Soc Dietary Life, 25, 830-841 (2015) 